\title{
Pure Sciences Students' Attitudes towards Learning English: The Case of University of Burundi
}

\section{Arcade Nduwimana ${ }^{1,2}$}

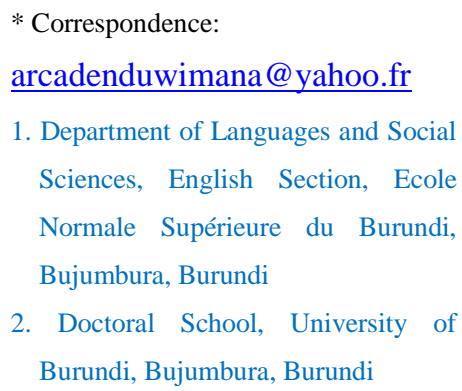

Received: 2 January 2019

Revision: 15 March 2019

Accepted: 7 April 2019

Published online: 20 June 2019

\begin{abstract}
Burundi is the sole country in East African Community (EAC) using mainly French as an official language and having a national language - Kirundi which is shared by nearly all Burundians. Therefore, English language is taught as a subject on the curriculum. Although English language is even taught to science university students in Burundi, it seems that the attitudes these students have towards learning English are not known. Thus, the present study was intended to investigate the attitudes that University of Burundi pure sciences students hold towards learning English. In doing so, it also examined whether there is a statistically significant difference in these students' attitudes in terms of gender and field of study. This study adopted a quantitative approach, hence a survey research design. The data were collected by means of a five-point Likert scale questionnaire raging from 'strongly disagree' to 'strongly agree' that was administered to a total number of 65 students enrolled in the faculty of sciences. The questionnaire was based on the tripartite model of attitude and consisted of 40 items. The collected data were analysed by means of descriptive and inferential statistics that were computed using the statistical package SPSS 22.The findings revealed that the afore-mentioned students have overall positive attitudes towards learning English. An analysis of the results also indicated that there is no statistically significant difference in students' attitudes both by gender and by field of study.
\end{abstract}

Keywords: attitudes, English language learning, pure sciences students, tripartite model 


\section{Introduction}

Currently, English is widely used in the world in most of - if not all - the walks of life. It is, as Crystal (2003) puts it, the global language. Indeed, it is predicted that by 2050 , half of the world population will be more or less proficient in English (The Economist, 2001; as cited in Johnson, 2009). It is therefore the dominant language in science and research, computing, internet, academia, and politics.

In science and research, the dominance of English is reflected in - for example - the number of works published in English. In fact, drawing on Anglo-Saxon bibliographic databases, Ammon (2003 as cited in Ferguson, 2007 ) reports that by 1995 , English accounted for $87.2 \%$ of journal publications in the natural sciences (e.g. biology, chemistry, physics, medicine, and mathematics) and $82.5 \%$ of publications in the social sciences (e.g. sociology, economics, etc.). According to Drubin and Kellogg (2012), by learning a single language (English), scientists around the world gain access to the vast scientific literature and can communicate with other scientists anywhere in the world. Given this rising status of English as a global language, it would not be unreasonable to say that learning English is a deemed necessity for scientists whose first language is not English and therefore would find themselves more disadvantaged to bypass it.

However, the learning process of English as a second or foreign language is influenced by many factors. One of the major factors is the learners' attitudes towards leaning English. The influence of attitudes in language learning is now widely acknowledged. According to Csizér and Dörnyei (2005), attitude is considered as a significant factor in foreign language learning process. Similarly, Smith (1971) argues that in a foreign language classroom, it is the students' attitudes that make life easy or difficult.

The concept of attitude in language learning has therefore become a subject of interest for many ESL scholars (Abidin et al., 2012; Ahmed, 2015; Eshghinejad, 2016; Ibrahim, Yana \& Yinusa, 2018; Karatas, Bademcioglu, \& Ergin, 2016; Martinović, \& Poljaković, 2011; Munir, 2015; Oroujlou \& Vahedi, 2011; Smith, 1971). Although these studies share the subject of investigation (attitudes), they were conducted in different contexts. To put it another way, they were undertaken in countries wherein the status and role of English language differ more or less from one country to another. Consequently, they should be taken with precaution and might not be generalised in other contexts.

In Burundi - the context of the present study, English was introduced for strategic purposes of diplomacy and international affairs after the country gained its independence in 1962 (Rwantabagu, 2011a). However, it is still dominated by French which has been and still is the predominant language used in the public life of the country - in education and administration together with Kirundi (Ntiranyibagira, 2017). Besides, Kirundi is the national language shared by nearly all Burundians. English is therefore spoken by less than $5 \%$ of the population (Mazunya \& Habonimana, 2010).

Since no study has yet investigated on the attitudes that non-English major students have towards learning English in such a context, this study is intended to fill the gap by examining the attitudes that pure sciences students hold toward learning English at the University of Burundi. A better understanding of students' attitudes will help English teachers, it is hoped, to address the specific English language needs of science students. In other words, it will provide teachers with part of the information needed in designing courses that would cater for the specific needs of these students. Indeed, such courses are expected to reflect the teaching of what is commonly known as English for Specific Purposes (ESP), a major subfield of English Language Teaching (ELT), which aims to meet the students' specific needs within a particular discipline (Dudley-Evans \& St John, 1998; Sabieh, 2018).

\subsection{Statement of the Problem}

Currently, there is a general agreement that attitudes and motivation have great influence on second language learning. For example, Gardner and Lambert (1972) - the prominent scholars on the influence of attitudes and motivation on second language achievement - argue that learners with a positive attitude and high level of motivation will be successful in developing proficiency in the language and vice versa. In line with this, Elyildirim and Ashton-Hay (2006) supports the idea that negative attitudes towards the foreign language can impede the learning of that language. Conversely, positive attitudes towards the foreign language increase language learning success.

In the literature on English language learning, there are several studies that investigated on attitudes and/or motivation. Some of these studies were conducted at secondary (or high) school level (Abidin et al., 2012; Khalid, 2016; Munir, 2015). Others were undertaken at tertiary level but focused on social sciences and humanities students (Karatas, 
Bademcioglu, \& Ergin, 2016). Only few of them were concerned with sciences students, still they focused on engineering students (Al-Tamimi \& Shuib, 2009; Martinović \& Poljaković, 2011). It seems that little attention was payed to pure sciences students. This study is therefore intended to bridge the gap by examining the attitudes that pure sciences students at the University of Burundi have towards learning English. What is more, these students are learning English with a French language learning background in a country wherein nearly all the population share one native language.

\subsection{Research Questions and Hypotheses}

This study attempted to provide answers to the following questions:

1. What are the attitudes of University of Burundi pure sciences students towards learning English?

2. Is there any statistically significant difference in these students' attitudes with regard to:

(a) Gender?

(b) Field of study?

It was then guided by the following hypotheses:

1. University of Burundi pure sciences students have negative attitudes towards learning English.

2. There is no statistically significant difference in attitudes of pure sciences students between male and female.

3. There is no statistically significant difference in attitudes of pure sciences students across fields of study.

\section{Literature Review}

\subsection{Definition of Attitudes}

Different scholars define the term attitude differently. According to Milton Rokeach (as cited in Smith, 1971), an attitude is a relatively enduring organization of beliefs around an object or a situation, predisposing one to respond in some preferential manner. For Eagly and Chaiken (1998 as cited in Munir, 2015), an attitude is a psychological tendency that is expressed by evaluating a particular entity with some degree of favour or disfavour. It follows that an attitude can be positive or negative.

In a number of studies, the concept of attitude in language learning usually goes hand in hand with that of motivation (Dörnyei, Csizér \& Németh, 2006; Oroujlou \& Vahedi, 2011; Stegmann, 2014; Ushida, 2005; Yu \&Watkins, 2010). However, the difference between the two concepts is not made clear in most of these studies. Angelovska (2007) reviewing Dörnyei, Csizér and Németh (2006), writes that the reader should be cautioned that, though the term motivation encompasses a broader spectrum of qualities than the term attitude, the authors use the terms attitudinal and motivational as synonyms throughout the book. On the other hand, according to Oroujlou and Vahedi (2011), the difference between attitude and motivation is that an attitude is a set of beliefs and motivation is a reason for doing something. The same authors argue that this can be confused because a set of beliefs (in something) can be a reason for doing it. Indeed, one may be motivated, they say, to learn English because of one's attitude towards English culture or English teacher. On reading Gardener's (1985) definition of motivation, it is clear that attitude is a component of motivation. His definition reads as "motivation refers to the combination of effort plus desire to achieve the goal of learning the language plus favourable attitudes toward learning the language" (p. 10).

According to Gardner (2001 as cited in Stegmann, 2014), attitude is one of the three dimensions of language learning. These are (1) students need to have a positive attitude towards L2 speakers, (2) General interest in foreign languages and a low ethnocentrism is needed to successfully engage in second language learning, and (3) Integrative motivation which is a genuine interest in learning the second languages in order to come closer to the other language community is of importance. It follows that attitude and motivation are interlinked.

\subsection{Influence of Attitudes and/or Motivation on Language Leaning}

Although the term 'motivation' does not appear in the title of this paper, it will be referred to in the discussion of the influence of attitudes on language learning. This is because these two concepts, as said above, are interlinked. Many scholars investigated the relationship between learner's attitudes and/ or motivation and language learning (Dörnyei, 1998; Gardner, 1985; Oroujlou \& Vahedi, 2011; Stegmann, 2014). According to Oroujlou and Vahedi (2011), having 
positive attitude towards learning a language is a good start to learn a language. The same authors argue that negative attitude and lack of motivation can lead to obstacles in learning a language. For them, a student's negative attitudes can be changed and turned into positive ones and facilitate getting a positive result. For Corder (1967 as cited in Stegmann, 2014), given motivation, it is inevitable that a human being will learn a second language if he is exposed to the language data. Similarly, Dörnyei (1998) argues that motivation provides the primary impetus to initiate learning the L2 and later the driving force to sustain the long and often tedious learning process.

\subsection{Three Aspect of Attitudes}

The concept of attitude is often classified into three aspects or components i.e. cognitive, affective (or emotional), and behavioural (Wenden, 1991 as cited in Abidin et al., 2012). These aspects make what is commonly known as a Tripartite Model of attitude. The cognitive aspect consists of the beliefs that language learners have about the knowledge they receive and how they understand language-learning process. The statement "I believe learning English is important to get a good job" is of a cognitive attitude.

Concerning the affective component, it involves language learners' feelings and emotions. In this respect, a language learning process is an emotional process that is consequently affected by different emotional factors (Feng \& Chen, 2009). A typical example of an affective attitude is the statement 'I enjoy the time I spend in English course.' With regard to behavioural aspect of attitude, it refers to the way learners behaves and reacts. The statement 'I always practice English with my classmates' is an example of behavioural attitude.

\subsection{Previous Findings}

The concept of attitudes in language learning has been extensively investigated by different scholars from different countries and at different levels of study. At secondary level, Munir (2015), for example, examined English language learning attitudes of the secondary school learners in District Lahore in Pakistan. His study concentrated on three main attitudinal features of language learning (cognitive, behavioural, and emotional). The results of his study showed that leaners have negative attitudes towards learning English. These results are in contrast with what one might expect considering the status of English in Paskistan. In fact, in this country, English has attained the status of powerful language compared with the national language, namely Urdu and a number of other local languages of Pakistan (Rassool \& Mansoor, 2009).

Like Munir (2015), the result of Abidin et al. (2012) indicates that the participants (secondary school learners in Libya) have a negative attitude towards learning English. Besides, their study revealed that there is a difference in the mean scores of the three aspects of attitudes towards English among the respondents. On the contrary, Khalid (2016), who also undertook a study on attitudes and motivational orientations of Pakistani learners towards the learning of English as a second language, reports that learners have a positive attitudes towards learning English as second language (ESL).

In Croatia, Martinović and Poljaković (2011) conducted a study at tertiary level. These researchers explored the attitudes of non-English major students at the University of Zadar in Croatia. The students were studying in the fields of Humanities and Social Sciences. The results of their studies indicate that students have positive attitudes towards learning English. A positive attitude towards learning English is also reported by Soleimani and Hanafi (2013). They investigated Iranian Medical students' attitudes towards learning English. Their study also indicated that the attitude of male students was higher than that of females.

Regarding whether there is a difference in students' attitudes towards learning English in terms of field of studies and/or gender, a study conducted in Thailand by Charoensuk and Jaipetch (2017) revealed a statistically significant difference in the overall attitudes of the six faculties. These results are consistent with those of Abidin et al. (2012). Their study concluded that there is a statistically significant difference in the participants' attitudes towards learning English language regarding the field of study. Similarly, Soleimani and Hanafi's (2013) study indicated that the attitude of male students was higher than that of females.

\section{Methodology}

\subsection{Research Design}

This study adopted a quantitative approach to research and employed a descriptive research design. According to De Vaus (2001), the fundamental question of descriptive research is "what is going on?" It is mainly concerned with the 
"what" of the research subject rather than the "why" of the research subject. To put it another way, descriptive researchers focus on what is happening rather than why it is happening. Besides answering the "what' questions, descriptive researchers usually expand their focus from "what" questions - describing a single variable - to "who," "when," and where" questions describing that variable's relationship to other variables (Mitchell \& Jolley, 2012). Although the focus of description research is the "what" questions, De Vaus (2001) argues that good description provokes the "why" questions - which is the concern of explanatory research. Indeed, before asking why a phenomenon is happening, one has to be able to describe accurately such a phenomenon.

The present study therefore measures the attitudes of pure sciences students towards learning English by means of a survey questionnaire. It does not account for why these attitudes are what they are. This might be the subject of further investigation by other researchers.

\subsection{Participants}

The participants in this study are second year students from the faculty of sciences at the University of Burundi. The researcher opted for second year students because they have a compulsory English course in first and second years. Four departments were represents in this study i.e. the department of maths (8), physics (12), chemistry (14), and biology (31) making a total number of 65 participants. Eleven of them were female while 54 were male. Because the targeted population was not too large, the researcher opted to study the entire population instead of selecting the sample. Therefore, all the targeted population were taken as participants in the study.

\subsection{Research Instrument}

As this study adopted a descriptive survey design, the instrument used was a survey questionnaire. The questionnaire was a five-point Likert scale questionnaire that was adapted from Abidin et al. (2012) and Eshghinejad (2016). The questionnaire consisted of 40 items in total. Of the 40 items, the first 10 were concerned with the affective aspect of attitude, the second 10 dealt with the behavioural aspect while the last 20 represented the cognitive one. All the 40 items were put to a five-point rating scale ranging from 'strongly disagree' to 'strongly agree.' Of the 40 items, 21 were positive while 19 were negative.

\subsubsection{Validity}

To ensure that the questionnaire comprehensively covers student's attitudes towards learning English, it was adopted from different previous studies on attitudes towards language learning. Besides, a feedback on the questionnaire was requested from the researcher's colleagues. They were requested to check for clarity, readability, and comprehensiveness of the questionnaire. Their comments were taken into account to get the final version of the questionnaire.

\subsubsection{Reliability}

To measure the internal consistency reliability of the questionnaire, the researcher used the Cronbach's alpha. The result indicated that the overall Cronbach's alpha coefficient was $(r=0.86)$. This shows that the questionnaire had a very high degree of internal consistency and hence was considered as reliable.

\subsection{Data Collection}

To collect data, the researcher himself administered a questionnaire. Because the targeted population was not too large (less than 80), the researcher prepared the copies of the questionnaires for the whole population. Therefore, all the students that were present on the day of administration were requested to complete the questionnaire. The valid completed copies obtained after administration added up to a total number of 65 .

\subsection{Data Analysis}

To analyse the data, the researcher first assigned scores for the responses obtained. For positive items, scores ranged from 1 ( $1=$ strongly disagree) to 5 ( $5=$ strongly agree). For negative items, the scores were reversed, that is, they ranged from 5 ( $5=$ strongly disagree) to 1 ( $1=$ strongly agree $)$. The data were then analysed by means of descriptive and inferential statistics. The statistics were computed using the statistical package SPSS 22. 


\section{Findings and Analysis}

\subsection{Findings for the First Research Question}

4.1.1 Overall Students' Attitudes towards Learning English

As presented on Table1, the surveyed students have overall positive attitudes towards learning English $(\mathrm{M}=3.82$, $\mathrm{SD}=.37)$. Hence, the first hypothesis is rejected. The table also indicates that all the three aspects of attitude scored above 3.5. While the cognitive aspect scored the highest $(\mathrm{M}=3.99, \mathrm{SD}=.44)$, the affective aspect scored the lowest $(\mathrm{M}=3.58, \mathrm{SD}=.43)$. It is noticed that there is no big difference in the mean scores of the three aspects.

Table 1. Descriptive statistics of students' overall attitudes towards learning English

\begin{tabular}{llllll}
\hline Attitudinal aspect & $\mathrm{N}$ & Minimum & Maximum & Mean & Std. Deviation \\
\hline Affective aspect & 65 & 2.50 & 4.80 & 3.58 & .43 \\
Behavioural aspect & 65 & 2.10 & 4.70 & 3.71 & .55 \\
Cognitive aspect & 65 & 2.75 & 4.80 & 3.99 & .44 \\
All aspects & 65 & 2.71 & 4.50 & 3.82 & .37 \\
\hline
\end{tabular}

4.1.2 Students' Attitudes with Regard to the Affective Aspect

Although the affective aspect scored the lowest, results on Table 1 indicated that students have positive affective attitudes towards learning English. Table 2 shows that of the ten items of the affective aspect, only three items scored less than 3. Both the item 6 and 7 scored 4.43. This means that the majority of students like to study English and are interested in English class. However, the same table indicates that they have fear of making mistakes when speaking in English (Item 10, M=2.30, SD=1.27).

Table 2. Descriptive statistics of students' attitudes with regard to the affective aspect

\begin{tabular}{|c|c|c|c|c|c|c|}
\hline$\overline{N^{\circ}}$ & Items in the questionnaire & $\mathrm{N}$ & Min & Max & Mean & SD \\
\hline 1. & I feel proud when studying English course & 64 & 1.00 & 5.00 & 4.14 & .794 \\
\hline 2. & I feel anxious when I have to speak in English & 62 & 1.00 & 5.00 & 3.17 & 1.420 \\
\hline 3. & I is very enjoyable to study English language at university & 63 & 1.00 & 5.00 & 4.22 & .812 \\
\hline 4. & I prefer to study in English rather than in French & 64 & 1.00 & 5.00 & 2.92 & 1.145 \\
\hline 5. & I wish I could speak English fluently & 64 & 1.00 & 5.00 & 3.82 & 1.091 \\
\hline 6. & I do not like to study English & 64 & 1.00 & 5.00 & 4.43 & .794 \\
\hline 7. & To tell the truth, I really have no interest in English class & 64 & 2.00 & 500 & 4.43 & .852 \\
\hline 8. & I look forward to the time I spend in English & 63 & 1.00 & 5.00 & 2.50 & 1.354 \\
\hline 9. & Studying English makes me feel more confident & 63 & 1.00 & 5.00 & 3.88 & 1.079 \\
\hline 10. & $\begin{array}{l}\text { When I am speaking in English, I have fear of making } \\
\text { mistakes }\end{array}$ & 65 & 1.00 & 5.00 & 2.30 & 1.273 \\
\hline
\end{tabular}

4.1.3 Students' Attitude with Regard to the Behavioural Aspect

Regarding the affective aspect of attitude, Table 3 indicates that all the items - except item $14(\mathrm{M}=2.79, \mathrm{SD}=1.24)$ scored above 3. This means that students have positive behavioural attitudes towards learning English. The item 20 
scored the highest $(\mathrm{M}=4.24, \mathrm{SD}=1.07)$; it shows that students agreed there should be English courses in science departments.

Table 3. Descriptive statistics of students' attitudes with regard to the behavioural aspect

\begin{tabular}{|c|c|c|c|c|c|c|}
\hline$\overline{\mathrm{N}^{\circ}}$ & Items in the questionnaire & $\mathrm{N}$ & Min & Max & Mean & SD \\
\hline 11. & I like to give opinions and ask question in English classes & 65 & 1.00 & 5.00 & 3.29 & 1.295 \\
\hline 12. & $\begin{array}{l}\text { When I hear someone speaking English, I like to practice with } \\
\text { him/her }\end{array}$ & 65 & 1.00 & 5.00 & 3.67 & 1.174 \\
\hline 13. & I put off my English homework as much as possible & 63 & 1.00 & 5.00 & 3.80 & 1.119 \\
\hline 14. & I like to practice English the way native speakers do & 63 & 1.00 & 5.00 & 2.79 & 1.246 \\
\hline 15. & I feel embarrassed to speak English in front of other students & 54 & 1.00 & 5.00 & 3.70 & 1.326 \\
\hline 16. & I like to practice English with my classmates & 65 & 1.00 & 5.00 & 3.29 & 1.271 \\
\hline 17. & $\begin{array}{l}\text { I do not pay any attention when my teacher is explaining the } \\
\text { lesson }\end{array}$ & 65 & 1.00 & 5.00 & 4.07 & 1.108 \\
\hline 18. & $\begin{array}{l}\text { When I miss a class/lesson, I never ask my friend or teachers } \\
\text { on what has been taught }\end{array}$ & 65 & 1.00 & 5.00 & 4.09 & .861 \\
\hline 19. & I usually skip English lessons & 65 & 1.00 & 5.00 & 4.13 & 1.058 \\
\hline 20. & $\begin{array}{l}\text { If I were an authority, I would ask for the removal of English } \\
\text { course in science departments }\end{array}$ & 65 & 1.00 & 5.00 & 4.24 & 1.075 \\
\hline
\end{tabular}

\subsubsection{Students' Attitude with Regard to the Cognitive Aspect}

As indicated above in Table 1, the affective aspect scored the highest $(M=3.99, S D=.44)$. Table 4 shows that of the 20 items, none scored less than three. While nine items scored between 3 and 4, twelve items scored above 4. This result shows that the surveyed students have positive beliefs towards learning English. The item $22(\mathrm{M}=4.34, \mathrm{SD}=.91)$ and the item $36(\mathrm{M}=4.56, \mathrm{SD}=.55)$ scored the highest. This means that students highly believe that knowledge of English will allow them to communicate with people all over the world and that listening, speaking, reading, and writing are all important in learning English.

Table 4. Descriptive statistics of students' attitudes with regard to the cognitive aspect

\begin{tabular}{|c|c|c|c|c|c|}
\hline $\mathrm{N}^{\circ}$ Items in the questionnaire & $\mathrm{N}$ & Min & Max & Mean & $\mathrm{SD}$ \\
\hline 21. Learning English will open more job opportunities for me & 65 & 1.00 & 5.00 & 3.81 & 1.42 \\
\hline $\begin{array}{l}\text { 22. Knowledge of English will allow me to communicate with people all } \\
\text { over the world }\end{array}$ & 64 & 1.00 & 5.00 & 4.34 & .91 \\
\hline 23. English is useful for furthering my education & 65 & 2.00 & 5.00 & 4.12 & .89 \\
\hline 24. Learning English will allow me to use foreign literature & 64 & 1.00 & 5.00 & 3.82 & 1.13 \\
\hline $\begin{array}{l}\text { 25. It is important to study English because it will make me more } \\
\text { educated. }\end{array}$ & 64 & 1.00 & 5.00 & 3.95 & 1.09 \\
\hline $\begin{array}{l}\text { 26. Learning English at university is important in order to ensure } \\
\text { continuity in language learning }\end{array}$ & 65 & 1.00 & 5.00 & 3.93 & .89 \\
\hline 27. English is a language with a lot of grammar & 65 & 1.00 & 5.00 & 3.12 & 1.29 \\
\hline
\end{tabular}


28. I have a goal (vision) to work in an English speaking country

$$
\begin{array}{lllll}
65 & 1.00 & 5.00 & 3.70 & 1.19 \\
65 & 1.00 & 5.00 & 3.84 & 1.22
\end{array}
$$

29. I study English just to pass the exam

30. Knowledge of English will help me know more about my field of study because I will be able to read books published in English

$\begin{array}{lllll}65 & 1.00 & 5.00 & 4.04 & .81\end{array}$

31. Frankly speaking, I don't believe English will ever be useful in my life.

$\begin{array}{lllll}65 & 1.00 & 5.00 & 4.20 & .97 \\ 64 & 1.00 & 5.00 & 4.17 & .88 \\ 63 & 1.00 & 5.00 & 3.73 & 1.16 \\ 65 & 1.00 & 5.00 & 4.32 & .92 \\ 65 & 2.00 & 5.00 & 4.30 & .74 \\ 64 & 3.00 & 5.00 & 4.56 & .55 \\ 65 & 1.00 & 5.00 & 4.21 & 1.02 \\ 65 & 1.00 & 5.00 & 4.00 & 1.04 \\ 65 & 1.00 & 5.00 & 4.12 & 1.11 \\ 63 & 1.00 & 5.00 & 3.61 & 1.19\end{array}$

32. Speaking is the most important skill I would like to improve

33. Listening is the least important skill in English learning

34. As a science student, there is no need to know how to write in English

35. In my opinion, it is very important to know how to read in English

36. I believe that 'listening, speaking, reading, writing' are all important in learning English.

37. I believe English is the language of Arts students not science students

38. In my opinion, English is a very difficult language and is therefore complicated to learn

39. People who are good at pure sciences (Maths, Physics, Chemistry and Biology) are not good at learning English

40. You should not say anything in English until you can say it correctly. $\begin{array}{llllll}63 & 1.00 & 5.00 & 3.61 & 1.19\end{array}$

\subsection{Findings for the Second Research Question}

In this section, the researcher analyses whether there is a statistically significant difference in students' attitudes with respect to gender and field of study. In order to provide answers to the second research question, inferential statistics namely the independent samples T-test and a oneway ANOVA were performed.

\subsubsection{Students' Attitudes in Terms of Gender}

In Table 5, the results indicate that although both male and female students have overall positive attitudes towards learning English, the mean score for male students $(\mathrm{M}=3.85, \mathrm{SD}=.38)$ is slightly higher than that of female $(\mathrm{M}=3.68$, $\mathrm{SD}=.26$ ). In order to analyse whether such a difference is statistically significant, an independent samples T-test was conducted. The SPSS output (Table $5 \&$ Table 6) shows that the mean score for male students' attitudes towards learning English $(\mathrm{M}=3.85, \mathrm{SD}=.38)$ is not statistically significant $(\mathrm{t}=1.30, \mathrm{df}=63$, two-tailed $\mathrm{p}=.19)$ from that of female $(\mathrm{M}=3.68, \mathrm{SD}=.26)$. Hence, the second hypothesis is supported.

Table 5. Descriptive statistics of students' overall attitude regarding gender

\begin{tabular}{llllll}
\hline & Sex & $\mathrm{N}$ & Mean & Std. Deviation & Std. Error Mean \\
\hline $\begin{array}{l}\text { Students' } \\
\text { attitudes }\end{array}$ & Male & 54 & 3.8535 & .38584 & .05251 \\
& Female & 11 & 3.6946 & .26291 & .07927 \\
\hline
\end{tabular}


Table 6. Independent Samples T-test of students' overall attitude regarding gender

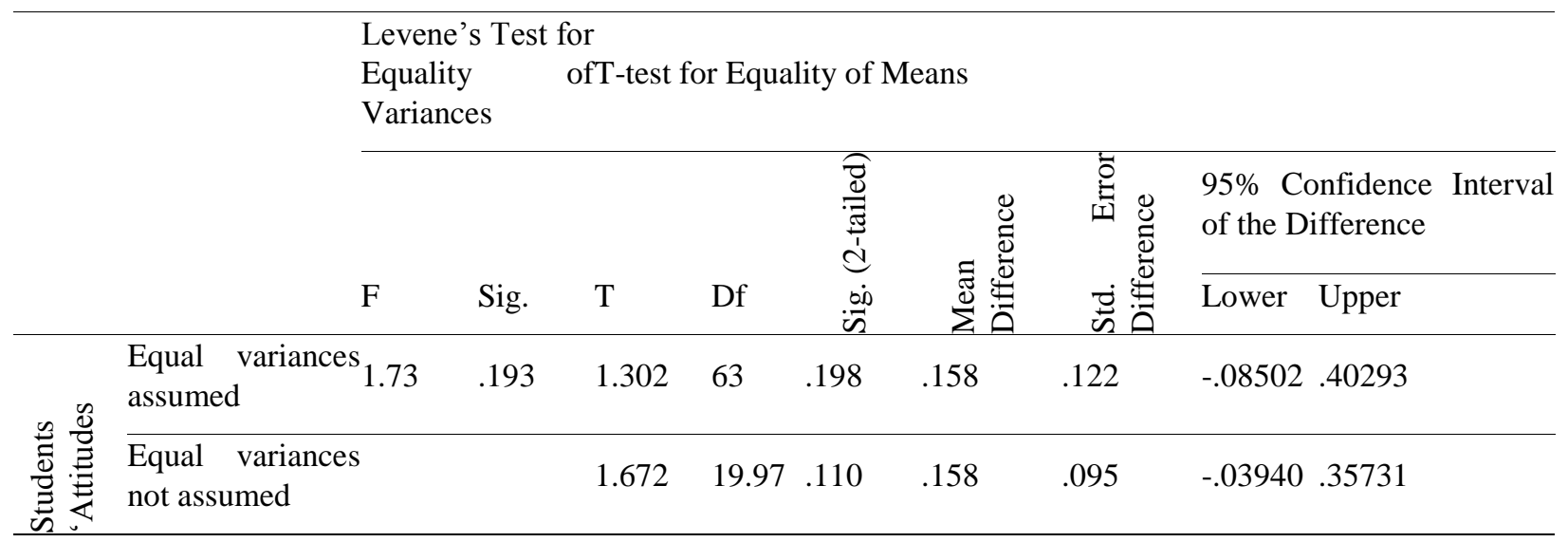

\subsubsection{Students' Attitudes in Terms of Field of Study}

With respect to students' overall attitudes by field of study, Table 7 shows that the means scores are different. While maths students scored the highest $(\mathrm{M}=3.97, \mathrm{SD}=.17)$, the biology students scored the lowest $(\mathrm{M}=3.81, \mathrm{SD}=.33)$. To analyse whether the means scores of students from the four departments are statically significant, a oneway ANOVA was carried out. The results of the ANOVA (Table 8) show that there is no statistically significant difference among the four groups in attitudes towards learning English $(\mathrm{F}=1.03, \mathrm{P}=.38>.05$. $)$. Hence the third hypothesis in supported.

Table 7. Descriptive statistics of students' overall attitude regarding field of study

\begin{tabular}{|c|c|c|c|c|c|c|c|c|}
\hline \multirow{2}{*}{ Field of study } & \multirow[b]{2}{*}{$\mathrm{N}$} & \multirow[b]{2}{*}{ Mean } & \multirow[b]{2}{*}{ Std. Deviation } & \multirow[b]{2}{*}{ Std. Error } & \multicolumn{3}{|c|}{$\begin{array}{l}95 \% \quad \text { Confidence } \\
\text { Interval for Mean }\end{array}$} & \multirow[b]{2}{*}{$\operatorname{Max}$} \\
\hline & & & & & $\begin{array}{l}\text { Lower } \\
\text { Bound }\end{array}$ & $\begin{array}{l}\text { Upper } \\
\text { Bound }\end{array}$ & Min & \\
\hline Maths & 8 & 3.97 & .17 & .063 & 3.82 & 4.12 & 3.68 & 4.21 \\
\hline Physics & 12 & 3.69 & .53 & .15 & 3.35 & 4.03 & 2.71 & 4.35 \\
\hline Chemistry & 14 & 3.87 & .36 & .09 & 3.66 & 4.09 & 3.28 & 4.50 \\
\hline Biology & 31 & 3.81 & .33 & .05 & 3.69 & 3.93 & 2.98 & 4.33 \\
\hline Total & 65 & 3.82 & .37 & .04 & 3.73 & 3.91 & 2.71 & 4.50 \\
\hline
\end{tabular}

Table 8. ANOVA Test

\begin{tabular}{llllll}
\hline & Sum of Squares & df & Mean Square & F & Sig. \\
\hline Between Groups & .428 & 3 & .143 & 1.038 & .382 \\
Within Groups & 8.385 & 61 & .137 & & \\
Total & 8.812 & 64 & & & \\
\hline
\end{tabular}




\section{Discussion}

The results obtained for the first research question showed that students have overall positive attitudes towards learning English. The same results revealed that the cognitive component scored the highest. These results are in line with those of Charoensuk and Jaipetch (2017) who investigated the attitudes of non-English major students at a university in Thailand. They reported that the participants in their study - as it is the case with the ones of the present study - were required to study English in a foreign language learning environment where there is little immediate need to use English for real communication. The same results (positive attitudes towards learning English) are reported in the studies of Martinović and Poljaković (2011) and of Soleimani and Hanafi (2013).

Contrary to the findings of the present study, Munir (2015) and Abidin et al. (2012) reported that the participants in their studies had negative attitudes towards learning English. In the present study, the positive attitudes of students towards learning English might have grown from the integration of Burundi in EAC (East African Community) in 2006 which led the government of Burundi to reconsider the status and role of English. Indeed, English was declared an official language in Burundi in 2014 (Uwimana, 2014) and is now taught from primary to tertiary level of education.

The findings revealed also that of the three components of attitudes, the affective component scored the lowest. This result corroborates Johnston's (2014) theory who argues that the affective component of attitude is the most difficult component to change. He continues to argue that our feelings are powerful and the way we feel cannot be changed as easily as the way we think or the way we behave. For this affective component, it was revealed that students have fear of making mistakes. This result is similar to Shams' (2008) who reported that most of the participants in his study were confused and nervous when they started to speak English in front of other students.

Regarding the second research question, the analysis of the results from the independent samples T-test showed that the attitudes of male students towards learning English is not statistically significantly different from that of female students. This finding is in contrast with Shoaib and Dornyei (2005 as cited in Abidin et al., 2012) who advocate that females show more interests, positive behaviours and performances compared with the males. Besides, it contradicts Eshghinejad (2016) and Abidin et al. (2012) who reported that female students' attitudes toward English are slightly higher than those of male.

Similarly, the results from the ANOVA indicate that students' attitudes do not statistically significantly differ in terms of field of study. This finding is in contrast with Charoensuk and Jaipetch's (2017) study which revealed a statistically significant difference in the overall attitudes of the six faculties at a university in Thailand.

\section{Implications of the Study}

The implications of this study are twofold. First, the overall attitude of Burundi sciences students towards learning English will help challenge the intuitive popular belief that science students dislike languages in general and English in particular. Second, with an understanding of science students' attitudes towards learning English, teachers will be equipped with one of the key components of the information needed to design English courses that will cater for the particular needs of the learners. It is notable that these students learned English not for specialization (or for the sake of learning), but because they need/will need it in their studies or professional life.

\section{Conclusion}

This study set out to investigate pure sciences students' attitudes towards learning English at the University of Burundi. The major findings indicated that the overall students 'attitudes are positive. It can be concluded that despite their French language learning background, pure sciences students are getting aware of the growing demands of English language worldwide and its predominance in science and research. Indeed, it was found out that students highly believe that knowledge of English will allow them to communicate with people all over the world and that listening, speaking, reading, and writing are all important in learning English. The findings also indicated that there is no statistically significant difference in students' attitudes in terms of both gender and field of study. It can be argued that the positive attitude of pure sciences students at the University of Burundi stems from the integration of Burundi in EAC and the students' growing awareness of the rising role and status of English language worldwide. 


\section{References}

Abidin, M. J. Z., Pour-Mohammadi, M., \& Alzwari, H. (2012). EFL students' attitudes towards learning English language: The case of Libyan secondary school students. Asian social science, 8(2), 119-134. http://dx.doi.org/10.5539/ass.v8n2p119

Ahmed, S. (2015). Attitudes towards English language learning among EFL learners at UMSKAL. Journal of Education and Practice, 6(18), 6-16. https://files.eric.ed.gov/fulltext/EJ1079681.pdf

Al-Tamimi, A., \& Shuib, M. (2009). Motivation and attitudes towards learning English: A study of petroleum engineering undergraduates at Hadhramout University of Sciences and Technology. GEMA Online® Journal of Language Studies, 9(2), 29-55. http://ejournal.ukm.my/gema/article/download/156/132

Angelovska, T. (2007). Review of the book Motivation, language attitudes and globalisation: A Hungarian perspective, by Z. Dörnyei, K. Csizér \& N. Németh]. Teachers College, Columbia University Working Papers in Applied Linguistics \& TESOL, 7(1), 1-3. http://dx.doi.org/10.7916/D8RF66J8

Charoensuk, V., \& Jaipetch, D. (2017). Attitudes toward English: A study of first-year students at King Mongkut's University of Technology North Bangkok. Journal of Advances in Humanities and Social Sciences, 3(1), 4257. doi: 10.20474/jahss-3.1.4

Crystal, D. (2003). English as a global language (2 ${ }^{\text {nd }}$ ed.). Cambridge: Cambridge University Press.

Csizér, K., \& Dörnyei, Z. (2005). The internal structure of language learning motivation and its relationship with language choice and learning effort. The Modern Language Journal, 89(1), 19-36. https://www.jstor.org/stable/pdf/3588549.pdf

De Vaus, D. (2001). Research design in social research. Great Britan: SAGE.

Dörnyei, Z., Csizér, K., \& Németh, N. (2006). Motivation, language attitudes and globalisation: A Hungarian perspective. Clevedon, England: Multilingual Matters.

Dörnyei, Z. (1998). Motivation in second and foreign language learning. Language teaching, 31(3), 117-135. http://www.test01.ippobuk.cv.ua/images/Motivation.pdf

Drubin, D. G., \& Kellogg, D. R. (2012). English as the universal language of science: opportunities and challenges. Molecular biology of the cell, 23(8), 1399. https://doi.org/10.1091/mbc.e12-02-0108

Dudley-Evans, T., \& St John, M. J. (1998). Developments in English for specific purposes: A multi-disciplinary approach. Cambridge: Cambridge University Press.

Elyildirim, S., \& Ashton-Hay, S. (2006). Creating positive attitudes towards English as a foreign language. English Teaching Forum, 44(4), 2-21. https://eprints.qut.edu.au/12256/1/12256.pdf

Eshghinejad, S. (2016). EFL students' attitudes toward learning English language: The case study of Kashan University students. Cogent education, 3(1), 1-13. http://dx.doi.org/10.1080/2331186X.2016.1236434

Feng, R., \& Chen, H. (2009). An analysis on the importance of motivation and strategy in postgraduate English acquisition. English Language Teaching, 2(3), 93-97. https://files.eric.ed.gov/fulltext/EJ1083053.pdf

Ferguson, G. (2007). The global spread of English, scientific communication and ESP: questions of equity, access and domain loss. Ibérica: Revista de la Asociación Europea de Lenguas para Fines Específicos (AELFE), 13, 738. https://dialnet.unirioja.es/descarga/articulo/2474003.pdf

Gardner, R. C. (1985). Social psychology and second language learning: the role of attitude and motivation. London: Edward Arnold.

Gardner, R. C., \& Lambert, W. E. (1972). Motivational variables in second language acquisition. In R.C. Gardner., \& W. Lambert (eds.) Attitudes and motivation in second language learning (pp. 119-216). Rowley, MA: Newbury House. 
Ibrahim, D., Yana, I. H., \& Yinusa, S. (2018). Measuring attitudinal disposition of undergraduate students to English language learning: The Nigerian University Experience. International Journal of Research in English Education, 3(1), 28-34. DOI: 10.18869/acadpub.ijree.2.2.10

Johnson, A. (2009). The rise of English: The language of globalization in China and the European Union. Macalester International, 22(1), 131-168. https://bit.ly/2F71Zir

Johnston, M. P. (2014). Secondary data analysis: A method of which the time has come. Qualitative and Quantitative Methods in Libraries (QQML), 3(3), 619-626.

Khalid, A. (2016). A study of the attitudes and motivational orientations of Pakistani learners toward the learning of English as a second language. SAGE Open, 6(3), https://doi.org/10.1177/2158244016665887

Karatas, H., Alci, B., Bademcioglu, M., \& Ergin, A. (2016). Examining university students' attitudes towards learning English using different variables. International Journal of Educational Researchers, 7(3), 12-20. http://dergipark.gov.tr/download/article-file/262414

Martinović, A., \& Poljaković, I. (2011). Attitudes toward ESP among university students. FLUMINENSIA: časopis za filološka istraživanja, 22(2), 145-161. https://hrcak.srce.hr/file/97888

Mazunya, M., \& Habonimana, A. (2010). Les langues de scolarisation dans l'enseignement fondamental en Afrique subsaharienne francophone: réalisation d'études bibliographiques et d'enquêtes de terrain. In MAEE et al. Les langues de scolarisation en Afrique francophone: Enjeux et repères pour l'action (pp. 94-147). Paris, France: Edition des archives contemporaines. http://www.elan-afrique.org/sites/default/files/fichiers attaches/rapport_lascolaf_cas_burundi.pdf

Mitchell, M. L., \& Jolley, J. M. (2012). Research design explained ( $7^{\text {th }}$ ed.). USA: Cengage Learning.

Munir, F. (2015). Attitudes of secondary school students towards English as Foreign Language: A case study at Lahore, Pakistan. International Journal of Research, 2(4), 637-650. doi: 10.6084/m9.figshare.4284458

Ntiranyibagira, C. (2017). La politique linguistique du Burundi: évolution et perspectives. Revue Sénégalaise de Langues et de Littérature, 10, 69-80. https://bit.ly/2F2ZKwm

Oroujlou, N., \& Vahedi, M. (2011). Motivation, attitude, and language learning. Procedia-Social and Behavioral Sciences, 29, 994-1000. https://doi.org/10.1016/j.sbspro.2011.11.333

Rassool, N., \& Mansoor, S. (2009). Contemporary issues in language, education and development in Pakistan. In N. Rasool (ed.), Global issues in language, education and development: Perspectives from post-colonial countries, 218-244. New Delhi: Orient Longman.

Rwantabagu, H. (2011a). Education in Burundi: An evolutionary perspective. Bujumbura, Burundi: University of Burundi.

Sabieh, C. (2018). English for specific purposes (ESP) testing. In J. I. Liontas (Ed.), The TESOL Encyclopedia of English Language Teaching, (pp. 14-19).USA: John Wiley \& Sons.

Shams, M. (2008). Students' attitudes, motivation and anxiety towards English language learning. Journal of Research, and Reflections in Education, 2(2), 121-144. https://ecommons.aku.edu/pakistan_ied_pdck/7

Smith, A. (1971). The importance of attitude in foreign language learning. The Modern Language Journal, 55(2), 8288. https://www.jstor.org/stable/pdf/321854.pdf

Soleimani, H., \& Hanafi, S. (2013). Iranian medical students' attitudes towards English language learning. International Research Journal of Applied and Basic Sciences, 4(12), 3816-3823. https://pdfs.semanticscholar.org/c70b/9479bef81f70224320ce262efec7947247f4.pdf

Stegmann, S. M. (2014). Motivation and attitudes towards second language learning at primary schools: A comparison of teaching programmes. Unpublished MA thesis. https://bit.ly/2QkzxLM

Ushida, E. (2005). The role of students' attitudes and motivation in second language learning in online language courses. CALICO journal, 23(1), 49-78. https://www.jstor.org/stable/pdf/24156232.pdf 
Yu B., Watkins D. (2010) Attitudes and motivation in second language acquisition: A study of international students in China from a cultural perspective. In Chapman D. W., Cummings W. K., \& Postiglione G. A. (Eds.), Crossing Borders in East Asian Higher Education. CERC Studies in Comparative Education, Vol. 27. Springer: Dordrecht.

Uwimana, D. (2014). English is now official language of Burundi. Iwacu English News. Retrieved from https://goo.gl/hktAc4 